\title{
Tropomyosin Isoform Expression in the Adductor Muscle of the Japanese Pearl Oyster, Pinctada fucata
}

\author{
Daisuke Funabara*, Ayaka Ohta, Jungo Sueyoshi, Satoshi Kanoh \\ Graduate School of Bioresources, Mie University, Tsu, Japan \\ Email: ^funabara@bio.mie-u.ac.jp
}

How to cite this paper: Funabara, D., Ohta, A., Sueyoshi, J. and Kanoh, S. (2019) Tropomyosin Isoform Expression in the Adductor Muscle of the Japanese Pearl Oyster, Pinctada fucata. American Journal of Molecular Biology, 9, 16-27.

https://doi.org/10.4236/ajmb.2019.91002

Received: November 13, 2018

Accepted: December 8, 2018

Published: December 11, 2018

Copyright $\odot 2019$ by authors and Scientific Research Publishing Inc. This work is licensed under the Creative Commons Attribution International License (CC BY 4.0).

http://creativecommons.org/licenses/by/4.0/

(c) (i) Open Access

\begin{abstract}
We determined the full-length primary structure of the tropomyosin (TM)-1 and -2 proteins from the adductor muscle of the Japanese pearl oyster Pinctada fucata (Pifuc-TM-1 and Pifuc-TM-2), and found that they are each composed of 284 amino acid residues. We predicted the gene structure of $P$. fucata TM (Pifuc-TM) using Splign alignment of our cDNA with genomic sequences and elucidated that Pifuc-TM consists of 10 exons. Exons $1-3$ and $5-10$ are used to transcribe Pifuc-TM-1 mRNA, and exons $1-4$ and $6-10$ are used to transcribe Pifuc-TM-2 mRNA. Both genes share the same start and stop codons located in exon 1 and exon 10, respectively. Using quantitative real-time PCR, we determined that the Pifuc-TM-1 gene was mainly expressed in adductor phasic muscle, and at a relatively weaker level in adductor catch muscle, whereas the Pifuc-TM-2 gene was expressed equally in both phasic and catch muscles. They were weakly expressed in gill and mantle. Immunoblot analysis using anti-Pifuc-TM-1 and anti-Pifuc-TM-2 antibodies revealed that adductor phasic muscle contained Pifuc-TM-1, while adductor catch muscle contained both Pifuc-TM-1 and Pifuc-TM-2. Differential scanning calorimetry (DSC) analysis was carried out for Pifuc-TM-1 and Pifuc-TM-2 expressed in bacteria, as well as TM purified from $P$. fucata phasic and catch muscle tissues (phasic-TM and catch-TM). The DSC data indicated that phasic-TM was mainly composed of Pifuc-TM-1, whereas catch-TM contained Pifuc-TM-1 and Pifuc-TM-2. These findings suggest that the distribution of Pifuc-TM-1 and Pifuc-TM-2 in adductor muscle is specific to the muscle fiber type, and reflects the properties of each.
\end{abstract}

\section{Keywords}

Adductor Muscle, Alternative RNA Processing, Catch Contraction, Pearl Oyster, Tropomyosin 


\section{Introduction}

Bivalve adductor muscles are composed of two muscle fiber types: phasic and catch. The larger phasic muscle is used for quick closure of shells, whereas the smaller catch muscle is involved in the sustained closure of shells. Catch muscles can develop a long-lasting high-tension state with little energy expenditure [1]. They begin to contract following an increase in intracellular $\mathrm{Ca}^{2+}$ concentrations, which activates myosin and develops the tension. They subsequently enter the catch state once $\mathrm{Ca}^{2+}$ concentrations decrease to resting levels. In the catch state, thin and thick filaments are thought to be tethered together by a complex of myosin, actin and twitchin, a giant myosin-associated protein [2] [3]. There are currently few data to suggest that thin filament-linked regulation is involved in catch contraction. However, molluscan muscle has the thin filament-related muscle proteins troponin complex ( $\mathrm{Tn})$, tropomyosin (TM) and calponin, which are known as the regulators of muscle contraction in vertebrates and serve to remind us that mollusks employ a similar regulatory system to that of vertebrate muscle [4]. We recently analyzed troponin C, a subunit of troponin, of the Japanese pearl oyster Pinctada fucata (Pifuc-TnC), and revealed that it is distributed only in phasic muscle, suggesting that troponin does not participate in the regulation of catch contraction [5]. Therefore, if there is thin filament-linked regulation associated with $\mathrm{Tn}$ in molluscan muscles, it might be operational in phasic muscle instead. In fact, it was reported that TM might be involved in the regulation of scallop striated muscle (i.e. non-catch muscle) via movement along different domains of actin filaments in a $\mathrm{Ca}^{2+}$ concentration manner [6].

TM consists of two parallel $\alpha$-helical polypeptides that form a coiled-coil structure and is localized along actin filaments. Muscle TM plays an important role in the regulation of skeletal muscle contraction in collaboration with $\mathrm{Tn}$. While much is known about vertebrate TM, the functions of TM in molluscan muscle regulation remain obscure, although various molluscan TM proteins have been studied [6]-[14]. The elucidation of thin filament-related regulation in molluscan muscle requires characterization of molluscan TM.

In our previous study, we determined partial sequences of two TM isoforms from $P$. fucata (Pifuc-TM-1 and Pifuc-TM-2) and raised the possibility that they are expressed by alternative RNA processing from a single gene [4]. In this study, we determined the full sequences of Pifuc-TM-1 and Pifuc-TM-2, predicted the gene structure of Pifuc-TM, and investigated the tissue distribution of the two isoforms.

\section{Materials and Methods}

\subsection{Animal Samples}

We obtained live specimens of $P$. fucata that were cultured in Ago Bay, Mie Prefecture, Japan. The adductor muscle, gill and mantle were dissected from each oyster body, immediately frozen in liquid nitrogen, and stored at $-80^{\circ} \mathrm{C}$ until use. 


\section{2. cDNA Cloning of Pifuc-TM-1 and Pifuc-TM-2}

Total RNA was extracted from the phasic part of the adductor muscle using a conventional method [15]. Partial nucleotide sequences of the $P$. fucata tropomyosin- 1 and -2 genes (Pifuc- TM-1 and Pifuc-TM-2) as determined by 3' RACE were reported previously [4]. To determine the full-length sequence of each, $5^{\prime}$ RACE was carried out using the 5' RACE system for Rapid Amplification of cDNA Ends, version 2.0 (Invitrogen, Carlsbad, CA, USA) using total RNA as a template. Primers were designed using the known sequences of Pifuc-TM-1 and Pifuc-TM-2. For Pifuc-TM-1, we used 5'- GATCCATTTGGCCTCAGATA-3' for synthesizing CDNA, 5'-ACTGTTTCTCCAGCACGTCT-3' for the first PCR, and 5'-GACCTCTCCTCTGATGCATT-3' for the second PCR. For Pifuc-TM-2 we used 5'-AACGTATTTAGCTTCTTTCA-3' for synthesizing cDNA, 5'-GTTGCTGTTCCAGGGCATCT-3' for the first PCR, and 5'-ATTCTCTCATCATCAGAGAC-3' for the second PCR. PCR was carried out using SapphireAmp Fast PCR Master Mix with the forward primers detailed above and the primers included in the kit. PCR conditions were as follows: 30 cycles of denaturation at $98^{\circ} \mathrm{C}$ for $5 \mathrm{~s}$, annealing at $55^{\circ} \mathrm{C}$ for $5 \mathrm{~s}$, and elongation at $72^{\circ} \mathrm{C}$ for $10 \mathrm{~s}$. The amplified DNA fragment was sequenced after insertion into a pTAC-1 vector. The determined sequences were registered in DDBJ/EMBL/ GenBank (accession numbers LC431553 and LC431554).

\subsection{Prediction of the Pifuc-TM Gene Structure}

The genome sequence including the Pifuc-TM gene was obtained by BLAST searching the Pifuc-TM-1 and Pifuc-TM-2 nucleotide sequences against the $P$. fucata genome database [16]. The gene structure of the Pifuc-TM gene was predicted by analyzing cDNA and genome sequences using the Splign alignment tool (NCBI).

\subsection{Gene Expression Analysis of Pifuc-TM-1 and Pifuc-TM-2 in Tissues}

The gene expression patterns of Pifuc-TM-1 and Pifuc-TM-2 in the catch and phasic muscles, gill and mantle were analyzed by quantitative real-time PCR. The cDNAs were synthesized using total RNA from each tissue as templates in

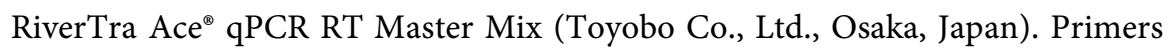
and probes were designed by Universal Probe Library Assay Design Center (Roche Diagnostics, Mannheim, Germany) using the distinct nucleotide sequences between Pifuc-TM-1 and Pifuc-TM-2. For Pifuc-TM-1, the primers used were: 5'-CTTGGAAAACCTGAACAATGC-3' (forward) and 5'-GGCCTCAGATAACTGTTTCTCC-3' (reverse), and a TaqMan probe 5'-CAGAGGAG-3'. For Pifuc-TM-2, the primers used were: 5'-AGAGAGTAGAAATGTCTCTGATGATGA-3' (forward) and 5'-TCCTCGGCAACGTATTTAGC-3' (reverse), and a TaqMan probe 5'-TGCCCTGG-3'. P. fucata $\beta$-actin (AF378128) was used as an internal standard. For $\beta$-actin, the primers used were 5'-TCGTTCCTCGGAATGGAA-3' 
(forward) and 5'-TCGACATCGCATTTGAGAAT-3' (reverse), and a TaqMan probe 5'-CAGAAGGAG-3'. The PCR reaction was performed using Eagle Taq Master Mix with ROX (Roche Diagnostics).

\subsection{Production of Anti-Pifuc-TM-1 and Pifuc-TM-2 Antibodies}

To produce anti-Pifuc-TM-1 antibodies, a peptide with a sequence of NLNNASEERSDVLEK encoded in exon 5 of Pifuc-TM-1 was used as an antigen after addition of cysteine residue to its $\mathrm{N}$-terminus to conjugate keyhole limpet hemocyanin as a carrier. For anti-Pifuc-TM-2 antibodies, a peptide with a sequence of SRNVSDDERIDALEQ encoded in exon 4 was used as an antigen similarly to anti-Pifuc-TM-1. Peptide synthesis and antibody production was performed by Sigma-Aldrich Japan.

\subsection{Protein Expression Analysis of Pifuc-TM-1 and Pifuc-TM-2 in Tissues}

Protein expression patterns of Pifuc-TM-1 and Pifuc-TM-2 in tissues of $P$. fucata were analyzed by immunoblotting using the antibodies described above. Catch and phasic muscles, gill and mantle were homogenized in phosphate-buffered saline and subjected to $10 \%$ SDS-PAGE, followed by electroblotting onto a polyvinylidene difluoride membrane. After blocking, the membrane was hybridized with anti-Pifuc-TM-1 or anti-Pifuc-TM-2 antibodies. Horseradish peroxidase-conjugated goat anti-rabbit IgG was used as a secondary antibody. Detection was carried out with Pierce ECL Western Blotting Substrate (ThermoFisher Scientific).

\subsection{Bacterial Expression and Purification of Pifuc-TM-1 and Pifuc-TM-2}

DNA fragments encoding Pifuc-TM-1 or Pifuc-TM-2, with codon usage optimized for expression in Escherichia coli, were commercially synthesized by GenScript Gene Synthesis Service (GenScript, Piscataway, NJ, USA) and inserted into the T7 expression vector pET21b (Novagen Darmstadt, Germany). To mimic acetylation, alanine and serine residues were added to the $\mathrm{N}$-terminus. $E$. coli BL21(DE3) transformed with pET-Pifuc-TM-1 or pET-Pifuc-TM-2 was cultured in auto-induction media at $37^{\circ} \mathrm{C}$ for $24 \mathrm{~h} \mathrm{[17].} \mathrm{The} \mathrm{E.} \mathrm{coli} \mathrm{cultures} \mathrm{were}$ collected by centrifugation and suspended in a lysis buffer included in the EzBactYeast Crusher kit (ATTO, Tokyo, Japan). Supernatants of the lysates obtained by centrifugation containing Pifuc-TM-1 or Pifuc-TM-2 were subjected to ion-exchange chromatography on a TSK-gel DEAE-5PW column $(7.5 \times 75$ $\mathrm{mm}$ ) (Tosoh, Tokyo, Japan) after dialysis against $50 \mathrm{mM}$ Tris- $\mathrm{HCl}(\mathrm{pH} 7.5)$ containing $30 \mathrm{mM} \mathrm{KCl}$ and $0.1 \mathrm{mM}$ DTT. The proteins were eluted with a linear gradient of $30 \mathrm{mM}$ to $600 \mathrm{mM} \mathrm{KCl}$.

\subsection{Purification of TM from Adductor Phasic and Catch Muscles}

TM was purified from the adductor phasic and catch muscles of $P$. fucata (phas- 
ic-TM and catch-TM, respectively) as described in a previous report [9]. The phasic adductor muscle acetone powder was extracted with 10 volumes of 20 $\mathrm{mM}$ Tris- $\mathrm{HCl}$ (pH 7.5) containing $1 \mathrm{M} \mathrm{KCl}$ and $5 \mathrm{mM}$ 2-mercaptoethanol overnight, followed by centrifugation at $10,000 \mathrm{~g}$ for $10 \mathrm{~min}$. The supernatant was subjected to isoelectric precipitation at $\mathrm{pH} 4.5$ adjusted with $1 \mathrm{M} \mathrm{HCl}$ and subjected to centrifugation at $10,000 \mathrm{~g}$ for $10 \mathrm{~min}$. The precipitate was dissolved in the least amount of water, and the $\mathrm{pH}$ was adjusted to 7.6 with $1 \mathrm{M} \mathrm{NaOH}$. Phasic-TM was fractionated with ammonium sulfate at $40 \%-45 \%$ saturation. The phasic-TM pellet was dissolved in the least amount of $50 \mathrm{mM}$ Tris- $\mathrm{HCl}(\mathrm{pH}$ 7.5) containing $30 \mathrm{mM} \mathrm{KCl}$ and $0.1 \mathrm{mM} \mathrm{DTT}$ and then subjected to ion-exchange chromatography on a TSK-gel DEAE-5PW column $(7.5 \times 75 \mathrm{~mm})$ equilibrated with the same buffer at a flow rate of $1 \mathrm{~mL} / \mathrm{min}$. The proteins were eluted with a linear gradient of $30 \mathrm{mM}$ to $600 \mathrm{mM} \mathrm{KCl}$. Equivalent procedures were used to purify catch-TM.

\subsection{Differential Scanning Calorimetry (DSC) Analysis of Pifuc-TM-1, Pifuc-TM-2, Phasic-TM and Catch-TM}

Pifuc-TM-1, Pifuc-TM-2, phasic-TM and catch-TM were subjected to DSC analysis after dialysis against $10 \mathrm{mM}$ sodium phosphate buffer ( $\mathrm{pH} 7.0$ ) containing $0.1 \mathrm{M} \mathrm{KCl}$ and $0.1 \mathrm{mM}$ DTT overnight. The external dialysis solution was used to adjust the protein solution to $2.0 \mathrm{mg} / \mathrm{mL}$ and served as a reference for DSC. DSC was performed using a Microcal VP-DSC (Malvern Panalytical Ltd., Malvern, UK). The thermal scanning was performed at $10^{\circ} \mathrm{C}$ to $80^{\circ} \mathrm{C}$ at a scanning rate of $1^{\circ} \mathrm{C} / \mathrm{min}$.

\section{Results}

\subsection{Molecular Characteristics of Pifuc-TM-1 and Pifuc-TM-2}

We used 5' RACE to determine $365 \mathrm{bp}$ of new sequence including the 5'-untranslated region of Pifuc-TM-1 and $362 \mathrm{bp}$ of new sequence of Pifuc-TM-2. Combined with known sequences, the full nucleotide sequences of Pifuc-TM-1 and Pifuc-TM-2 were determined in this study (Figure 1). The two sequences were found to be identical except for the region from 530 - 633 from the $5^{\prime}$-end of the Pifuc-TM-1 sequence. The open reading frame of Pifuc-TM-1 begins at 155 from the 5 -end and encodes 284 amino acid residues (Figure 2). Pifuc-TM-2 also has a sequence encoding 284 residues from the same position. The two sequences were identical except for residues 126 - 160 from the N-terminus. The N-terminal sequences of Pifuc-TM-1 and Pifuc-TM-2 are MDAIKKKM, a well-conserved sequence in TM regardless of the species. TFAELAGY at the C-terminus is a well-conserved sequence in molluscs.

\subsection{Gene Structure of Pifuc-TM}

BLAST searching with our Pifuc-TM-1 and Pifuc-TM-2 nucleotide sequences against the genome database of $P$. fucata yielded a single nucleotide sequence of 
scaffold121.1. In our previous study, we annotated a gene model (pfu_aug1.0_6509.1_67448) that was automatically predicted by the genome database to be Pifuc-TM-1, which contained a predicted sequence that was identical to the sequence of Pifuc-TM-1 determined in this study. The gene model did not contain a sequence specific to Pifuc-TM-2. We then predicted the gene structure of Pifuc-TM using Splign alignment of the cDNA and genome sequences (Figure 3). The Pifuc-TM gene consists of 10 exons. Exons 1, 2, 3, 6, 7, 8, 9 and 10 are common to Pifuc-TM-1 and Pifuc-TM-2, while exon 4 is used for Pifuc-TM-2 and exon 5 for Pifuc-TM-1. Pifuc-TM-1 and Pifuc-TM-2 use the same start and stop codons, which are located in exon 1 and exon 10, respectively.

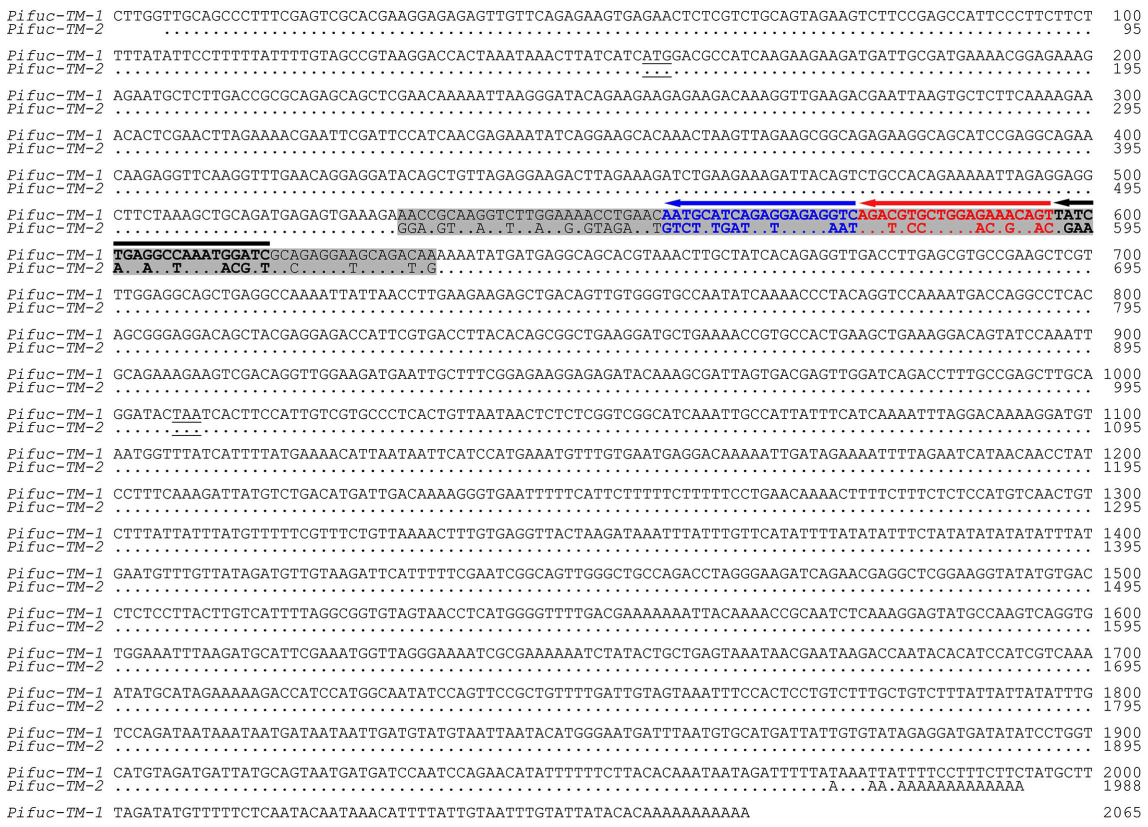

Figure 1. Nucleotide sequences of the Pinctada fucata tropomyosin-1 and -2 (Pifuc-TM-1 and Pifurc-TM-2) genes. Distinct sequences between Pifuc-TM-1 and Pifuc-TM-2 are shaded. The numbers on the right of the sequences denote nucleotides from the 5 -end. The start and stop codons are underlined. Positions of primers used for cDNA cloning are represented by arrows above the sequences.

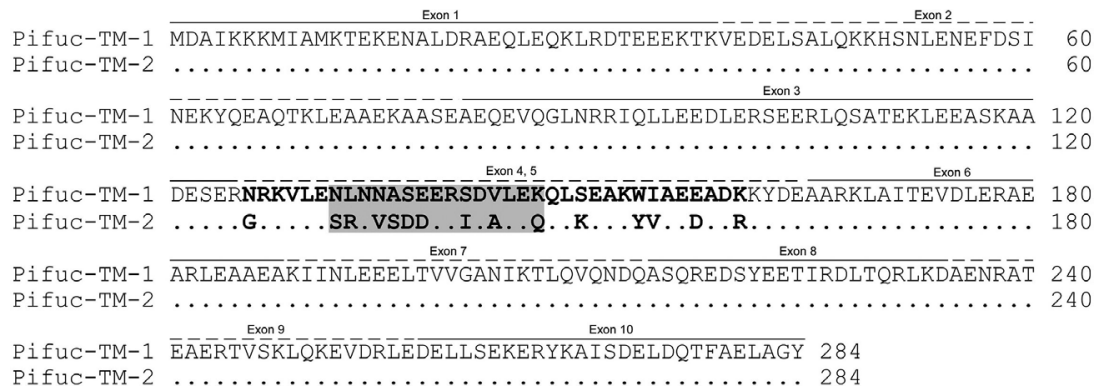

Figure 2. Deduced amino acid sequences of Pinctada fucata tropomyosin-1 and -2 (Pifuc-TM-1 and Pifuc-TM-2). Segments encoded by the nucleotide sequences that were shaded in Figure 1 are in boldface. Solid and dashed lines above the sequences represent regions of exons. Sequences used for antibody production are shaded. 


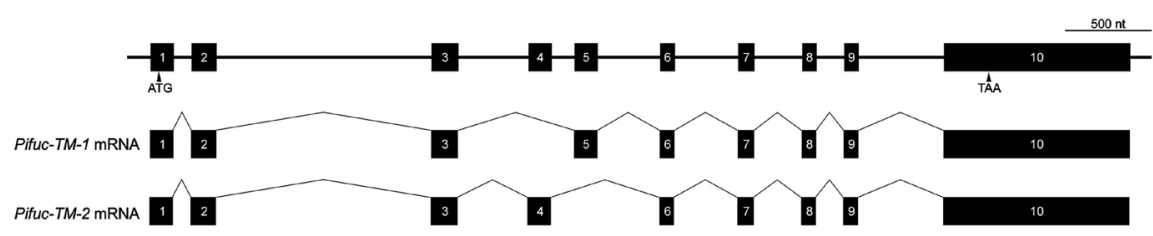

Figure 3. Gene structure of Pinctada fucata tropomyosin. Black boxes indicate exons, and intervening lines represent introns. The ATG start codon and TAA stop codons are indicated. Exons $1-3$ and 5 - 10 are used to transcribe Pifuc-TM-1 mRNA, and exons $1-4$ and 6 - 10 for Pifuc-TM-2 mRNA.

\subsection{Gene and Protein Expression Analyses of Pifuc-TM-1 and Pifuc-TM-2}

Gene expression analysis showed that the Pifuc-TM-1 gene was predominantly expressed in adductor phasic muscle, while relatively weaker expression was detected in catch muscle; the Pifuc-TM-2 gene was expressed equally in phasic and catch muscle (Figure 4). Both genes were barely detectable in gill and mantle. These findings remind us that the two isotype proteins Pifuc-TM-1 and Pifuc-TM-2 were differentially expressed in the two muscle types. Immunoblotting using antibodies that specifically recognize Pifuc-TM-1 and Pifuc-TM-2 was carried out to analyze the protein expression profiles in $P$. fucata tissues (Figure 5). The results revealed that Pifuc-TM-1 was present in adductor catch and phasic muscles, whereas Pifuc-TM-2 was present only in catch muscle. Neither Pifuc-TM-1 nor Pifuc-TM-2 was detected in gill or mantle. Paramyosin, which has a similar structure to TM in that it consists of an $\alpha$-helix that spans the entire molecule, was nonspecifically detected by the anti-Pifuc-TM-1 and anti-Pifuc-TM-2 antibodies (Figure 5(B) and Figure 5(C)). Taken together, the data suggested that adductor phasic muscle contained mainly Pifuc-TM-1 while adductor catch muscle contained equally amounts of both Pifuc-TM-1 and Pifuc-TM-2. To confirm this result, we performed DSC analysis using TM purified from adductor phasic (phasic-TM) and catch muscle (catch-TM), and bacterially expressed Pifuc-TM-1 and Pifuc-TM-2.

\subsection{DSC Analysis of Pifuc-TM-1, Pifuc-TM-2, Phasic-TM and Catch-TM}

All DSC thermograms of Pifuc-TM-1, Pifuc-TM-2, phasic-TM and catch-TM had two peaks (labeled as $T_{\mathrm{m}} 1$ and $T_{\mathrm{m}} 2$ in the order of temperature from low to high) (Figure 6). The $T_{\mathrm{m}} 1$ values were $46.49^{\circ} \mathrm{C}$ for Pifuc-TM-1, $47.20^{\circ} \mathrm{C}$ for Pifuc-TM-2, $46.65^{\circ} \mathrm{C}$ for phasic-TM and $46.83^{\circ} \mathrm{C}$ for catch-TM. The $T_{\mathrm{m}} 2$ values were $54.34^{\circ} \mathrm{C}$ for Pifuc-TM-1, $53.71^{\circ} \mathrm{C}$ for Pifuc-TM-2, $51.34^{\circ} \mathrm{C}$ for phasic-TM and $53.75^{\circ} \mathrm{C}$ for catch-TM. Thus, all of the TM molecules had similar $T_{\mathrm{m}}$ values. However, Pifuc-TM-1 and Pifuc-TM-2 had thermograms that differed based on the distinct sequences between them. A comparison of the heights of the $T_{\mathrm{m}} 2$ peaks implied that catch-TM is composed of both $\mathrm{Pi}$ fuc-TM-1 and Pifuc-TM-2. 


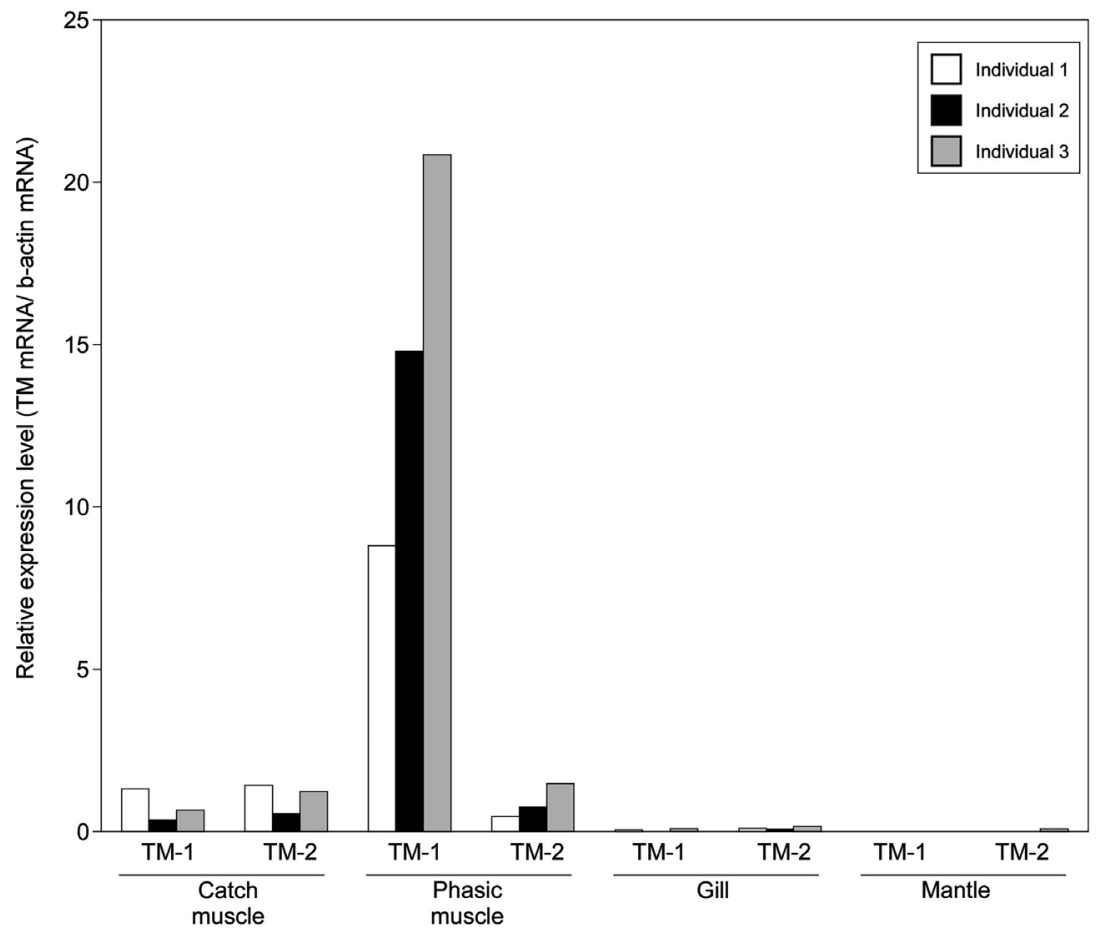

Figure 4. Gene expression patterns of Pifuc-TM-1 and Pifuc-TM-2 in Pinctada fucata tissues. Quantitative real-time PCR analysis was performed to examine Pifuc-TM-1 and Pifuc-TM-2 gene expression in $P$. fucata adductor catch muscle, adductor phasic muscle, gill and mantle. The data shown are from three independent experiments. The y-axis indicates relative gene expression levels using $\beta$-actin as an internal standard.
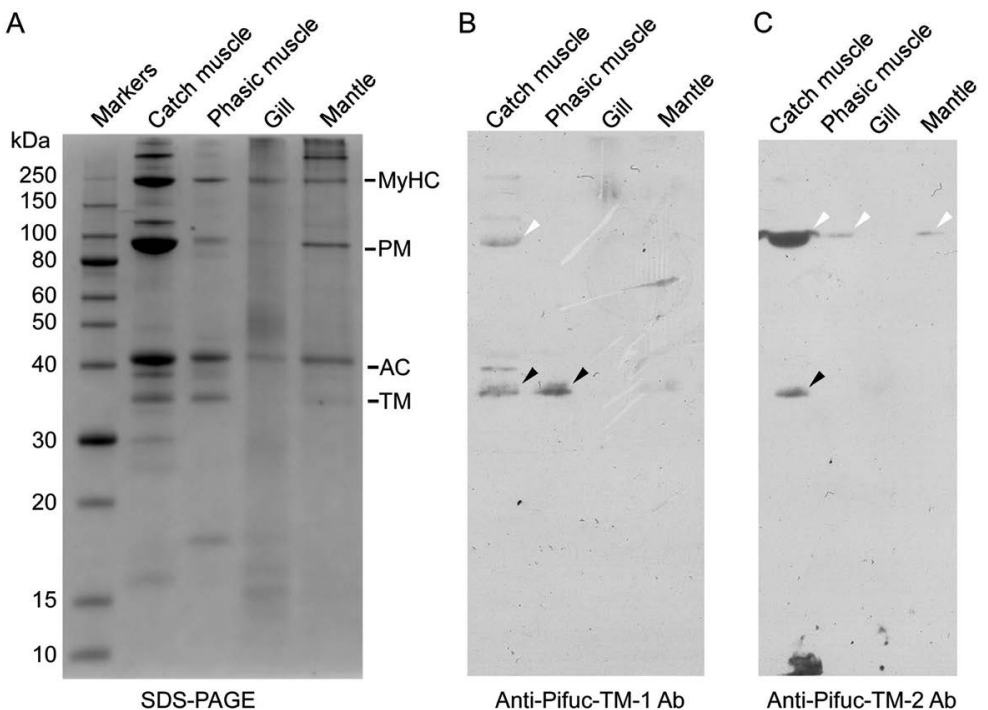

Figure 5. Protein expression patterns of Pifuc-TM-1 and Pifuc-TM-2 in Pinctada fucata tissues. Immunoblotting analysis was performed to examine Pifuc-TM-1 and Pifuc-TM-2 in $P$. fucata adductor catch muscle, adductor phasic muscle, gill and mantle. (A) SDS-PAGE patterns of each tissue homogenate, showing myosin heavy chain (MyHC), paramyosin (PM), actin (AC), and tropomyosin (TM). The polyvinylidene difluoride membrane reacted with anti-Pifuc-TM-1 antibodies (B) and anti-Pifuc-TM-2 antibodies (C). Black arrow heads indicate TM bands. White arrow heads indicate the nonspecific detection of PM. 
A

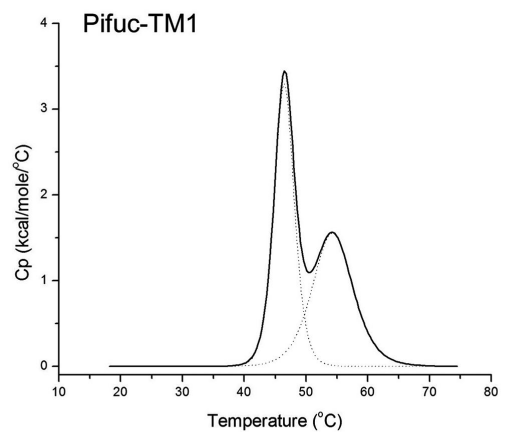

C

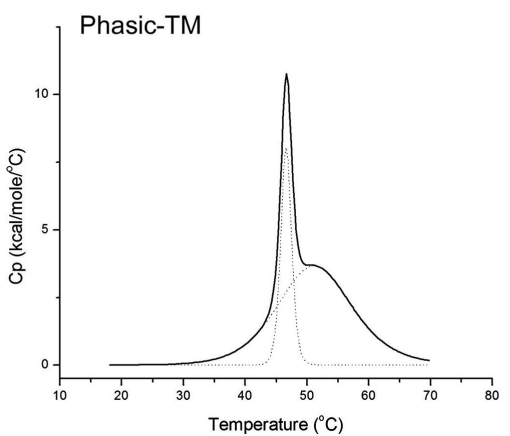

B

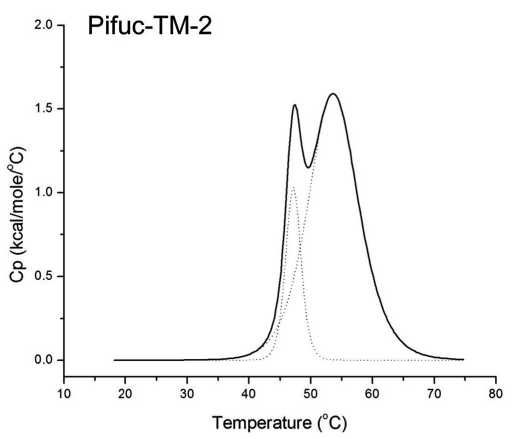

D

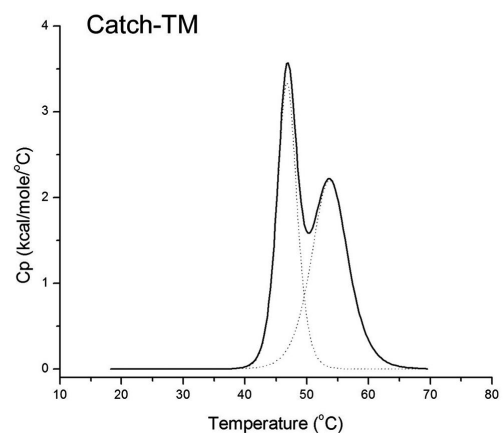

Figure 6. Differential scanning calorimetric (DSC) analysis. DSC thermograms of bacterially expressed Pifuc-TM-1 (A) and Pifuc-TM-2 (B), and phasic-TM (C) and catch-TM (D) purified from Pinctada fucata tissues. $\mathrm{Cp}=$ measured heat capacity.

\section{Discussions}

We determined that, like other muscle TMs, the full sequences of Pifuc-TM-1 and Pifuc-TM-2 consist of 284 amino acid residues (Figure 1 and Figure 2). The distinct sequence segment (residues 126 - 160) of Pifuc-TM-1 and Pifuc-TM-2 includes a region considered to be involved in interaction with troponin $\mathrm{T}(\mathrm{TnT})$ [18], implying that the affinity of TnT to Pifuc-TM possibly depends on isoform types. As shown in Figure 4 and Figure 5, Pifuc-TM-2 was mainly expressed only in phasic muscle. It was reported in a scallop striated muscle study that the movement of TM was induced by the $\mathrm{Ca}^{2+}$ concentration, as it is in vertebrates [6]. Pifuc-TM-2 might be involved in phasic muscle regulation in collaboration with Tn, which is expressed mainly in phasic muscle [5] [19].

TM molecules are joined together by a head-to-tail interaction of eight to nine residues at the $\mathrm{N}$ and C-termini. A sequence of MDAIKKKM at the $\mathrm{N}$-terminus is well conserved across vertebrates and invertebrates, including both Pifuc-TM-1 and Pifuc-TM-2 (Figure 2). Conversely, at the C-terminus, vertebrate TM has a sequence of ALNDMTSI, whereas molluscan TM, including Pifuc-TM-1 and Pifuc-TM-2, has a sequence of TFAEL(I) AGY. This difference at the C-terminal sequence possibly confers differences in TM assembly and muscle regulation. It was reported that TM in different bivalves inhibited the Mg-ATPase activity of rabbit reconstituted actomyosin, and that the relative viscosities in the absence of $\mathrm{KCl}$ were 3.5 - 6 times higher than those of vertebrate TMs [11]. Taken together, these data suggest that Pifuc-TM-1 and Pifuc-TM-2 might have distinct 
functions from the isotypes of vertebrate TM.

It is well known that many TM variants are produced by alternative RNA processing that is tissue specific [20]. In this study, we revealed that Pifuc-TM-1 and Pifuc-TM-2 are synthesized from a single gene and that their expression patterns are different in adductor phasic and catch tissue, suggesting that the adductor muscle selectively employs tropomyosin isoforms for different muscle functions. A study of scallop adductor muscle that parallels the results of this study showed that different myosin heavy chain isoforms produced by alternative RNA processing from a single gene were used selectively in striated and catch muscles [21]. Our previous reports showed that isoforms of twitchin and calponin are selectively used in scallop striated and catch muscles [22] [23]. Different properties that distinguish phasic and catch muscles in bivalves might be derived from isoforms of muscle proteins that are produced by alternative RNA processing. Although molluscan muscle TM has been widely studied, there are few reports of genomic analysis. In this study, a BLAST search against the $P$. fucata genome database yielded only one scaffold including the $T M$ gene, indicating that there is one TMgene in the $P$. fucata genome. It was reported that there might be multiple TM genes in the genome of the mussel Mytilus galloprovincialis [7]. Numbers of TM genes might depend on the mollusc species.

We recently showed that $\mathrm{TnC}$, a subunit of $\mathrm{Tn}$, might participate in the regulation of phasic muscle by virtue of its molecular characterization [5] [19]. In this study, DSC analysis clearly revealed that the types of TM isolated from phasic and catch muscles are different (Figure 6), raising the possibility that $\mathrm{Tn}$ might interact with Pifuc-TM-1. However, how TnC collaborates with other subunits of Tn to regulate molluscan muscle contraction is unclear. Molluscan $\mathrm{TnI}$ and $\mathrm{TnT}$ are considered to have different characteristics from those of vertebrates [24] [25] [26] [27]. To better understand the molecular mechanism of molluscan muscle contraction regulation, we need to elucidate the functions of the Tn subunits, and the interaction between Tn and TM.

\section{Acknowledgements}

This study was supported by JSPS KAKENHI Grant Number JP16K07872. We thank Michelle Kahmeyer-Gabbe, PhD, from Edanz Group (http://www.edanz.com/ac) for editing a draft of this manuscript.

\section{Conflicts of Interest}

The authors declare no conflicts of interest regarding the publication of this paper.

\section{References}

[1] Funabara, D., Kanoh, S., Siegman, M.J., Butler, T.M., Hartshorne, D.J. and Watabe, S. (2005) Twitchin as a Regulator of Catch Contraction in Molluscan Smooth Muscle. Journal of Muscle Research and Cell Motility, 26, 455-460. https://doi.org/10.1007/s10974-005-9029-2 
[2] Funabara, D., Hamamoto, C., Yamamoto, K., Inoue, A., Ueda, M., Osawa, R., Kanoh, S., Hartshorne, D.J., Suzuki, S. and Watabe, S. (2007) Unphosphorylated Twitchin Forms a Complex with Actin and Myosin that May Contribute to Tension Maintenance in Catch. Journal of Experimental Biology, 210, 4399-4410. https://doi.org/10.1242/jeb.008722

[3] Funabara, D., Osawa, R., Ueda, M., Kanoh, S., Hartshorne, D.J. and Watabe, S. (2009) Myosin Loop 2 Is Involved in the Formation of a Trimeric Complex of Twitchin, Actin, and Myosin. The Journal of Biological Chemistry, 284, 18015-18020. https://doi.org/10.1074/jbc.M109.016485

[4] Funabara, D., Watanabe, D., Satoh, N. and Kanoh, S. (2013) Genome-Wide Survey of Genes Encoding Muscle Proteins in the Pearl Oyster, Pinctada fucata. Zoological Science, 30, 817-825. https://doi.org/10.2108/zsj.30.817

[5] Funabara, D., Urakawa, Y. and Kanoh, S. (2018) Molecular Cloning and Tissue Distribution of Troponin C from the Japanese Pearl Oyster, Pinctada fucata. American Journal of Molecular Biology, 8, 166-177. https://doi.org/10.4236/ajmb.2018.83014

[6] Jung, H.S. and Craig, R. (2008) $\mathrm{Ca}^{2+}$-Induced Tropomyosin Movement in Scallop Striated Muscle Thin Filaments. Journal of Molecular Biology, 383, 512-519.

https://doi.org/10.1016/j.jmb.2008.08.051

[7] Iwasaki, K., Kikuchi, K., Funabara, D. and Watabe, S. (1997) cDNA Cloning of Tropomyosin from the Anterior Byssus Retractor Muscle of Mussel and Its Structural Integrity from the Deduced Amino Acid Sequence. Fisheries Science, 63, 731-734. https://doi.org/10.2331/fishsci.63.731

[8] Ozawa, H., Watabe, S. and Ochiai, Y. (2011) Thermodynamic Characterization of Muscle Tropomyosins from Marine Invertebrates. Comparative Biochemistry and Physiology Part B: Biochemistry and Molecular Biology, 160, 64-71. https://doi.org/10.1016/j.cbpb.2011.06.001

[9] Ozawa, H., Watabe, S. and Ochiai, Y. (2010) Thermostability of Striated and Smooth Adductor Muscle Tropomyosins from Yesso Scallop Mizuhopectenyessoensis. Journal of Biochemistry, 147, 823-832. https://doi.org/10.1093/jb/mvq018

[10] Degnan, B.M., Degnan, S.M. and Morse, D.E. (1997) Muscle-Specific Regulation of Tropomyosin Gene Expression and Myofibrillogenesis Differs among Muscle Systems Examined at Metamorphosis of the Gastropod Haliotisrufescens. Development Genes and Evolution, 206, 464-471. https://doi.org/10.1007/s004270050076

[11] Nishimura, Y., Ojima, T. and Nishita, K. (1997) Bivalve Tropomyosins Exhibit Strong Inhibition of Actomyosin Mg-ATPase and High Viscosity. Fisheries Science, 63, 802-806. https://doi.org/10.2331/fishsci.63.802

[12] Inoue, A., Ojima, T. and Nishita, K. (1999) Cloning and Sequencing of cDNA for Akazara Scallop Tropomyosin. Fisheries Science, 65, 772-776.

https://doi.org/10.2331/fishsci.65.772

[13] Hasegawa, Y. (2001) Complete Nucleotide Sequences of cDNA Encoding for Tropomyosin Isoforms from the Catch Muscle of Scallop Patinopecten yessoensis. Fisheries Science, 67, 988-990. https://doi.org/10.1046/j.1444-2906.2001.00352.x

[14] Fujinoki, M., Ueda, M., Inoue, T., Yasukawa, N., Inoue, R. and Ishimoda-Takagi, T. (2006) Heterogeneity and Tissue Specificity of Tropomyosin Isoforms from Four Species of Bivalves. Comparative Biochemistry and Physiology Part B: Biochemistry and Molecular Biology, 143, 500-506. https://doi.org/10.1016/j.cbpb.2006.01.002

[15] Chomczynski, P. (1993) A Reagent for the Single-Step Simultaneous Isolation of RNA, DNA and Proteins from Cell and Tissue Samples. BioTechniques, 15, 532-534, 
536-537.

[16] Takeuchi, T., Kawashima, T., Koyanagi, R., Gyoja, F., Tanaka, M., Ikuta, T., Shoguchi, E., Fujiwara, M., Shinzato, C., Hisata, K., Fujie, M., Usami, T., Nagai, K., Maeyama, K., Okamoto, K., Aoki, H., Ishikawa, T., Masaoka, T., Fujiwara, A., Endo, K., Endo, H., Nagasawa, H., Kinoshita, S., Asakawa, S., Watabe, S. and Satoh, N. (2012) Draft Genome of the Pearl Oyster Pinctada fucata: A Platform for Understanding Bivalve Biology. DNA Research, 19, 117-130.

https://doi.org/10.1093/dnares/dss005

[17] Studier, F.W. (2005) Protein Production by Auto-Induction in High-Density Shaking Cultures. Protein Expression and Purification, 41, 207-234. https://doi.org/10.1016/j.pep.2005.01.016

[18] White, S.P., Cohen, C. and Phillips Jr., G.N. (1987) Structure of Co-Crystals of Tropomyosin and Troponin. Nature, 325, 826-828. https://doi.org/10.1038/325826a0

[19] Funabara, D., Ishikawa, D., Urakawa, Y. and Kanoh, S. (2018) $\mathrm{Ca}^{2+}$-Induced Conformational Change of Troponin C from the Japanese Pearl Oyster, Pinctada fucata. American Journal of Molecular Biology, 8, 205-214. https://doi.org/10.4236/ajmb.2018.84018

[20] Perry, S.V. (2001) Vertebrate Tropomyosin: Distribution, Properties and Function. Journal of Muscle Research and Cell Motility, 22, 5-49. https://doi.org/10.1023/A:1010303732441

[21] Nyitray, L., Jancso, A., Ochiai, Y., Graf, L. and Szent-Gyorgyi, A.G. (1994) Scallop Striated and Smooth Muscle Myosin Heavy-Chain Isoforms are Produced by Alternative RNA Splicing from a Single Gene. Proceedings of the National Academy of Sciences of the United States of America, 91, 12686-12690. https://doi.org/10.1073/pnas.91.26.12686

[22] Funabara, D., Watabe, S. and Kanoh, S. (2015) Phosphorylation Properties of Twitchin from Yesso Scallop Catch and Striated Muscles. Fisheries Science, 81, 541-550. https://doi.org/10.1007/s12562-015-0866-7

[23] Funabara, D., Watabe, S. and Kanoh, S. (2015) Molecular Characterization of Calponin in the Catch Muscle of the Yesso Scallop Mizuhopecten yessoensis. Fisheries Science, 81, 155-162. https://doi.org/10.1007/s12562-014-0825-8

[24] Inoue, A., Ojima, T. and Nishita, K. (1996) Cloning and Sequencing of a cDNA for Akazara Scallop Troponin T. Journal of Biochemistry, 120, 834-837. https://doi.org/10.1093/oxfordjournals.jbchem.a021487

[25] Tanaka, H., Ojima, T. and Nishita, K. (1998) Amino Acid Sequence of Troponin-I from Akazara Scallop Striated Adductor Muscle. Journal of Biochemistry, 124, 304-310. https://doi.org/10.1093/oxfordjournals.jbchem.a022112

[26] Yumoto, F., Nara, M., Kagi, H., Iwasaki, W., Ojima, T., Nishita, K., Nagata, K. and Tanokura, M. (2001) Coordination Structures of $\mathrm{Ca}^{2+}$ and $\mathrm{Mg}^{2+}$ in Akazara Scallop Troponin C in Solution. European Journal of Biochemistry, 268, 6284-6290. https://doi.org/10.1046/j.1432-1327.2001.02583.x

[27] Tanaka, H., Takeya, Y., Doi, T., Yumoto, F., Tanokura, M., Ohtsuki, I., Nishita, K. and Ojima, T. (2005) Comparative Studies on the Functional Roles of N- and C-Terminal Regions of Molluskan and Vertebrate Troponin-I. The FEBS Journal, 272, 4475-4486. https://doi.org/10.1111/j.1742-4658.2005.04866.x 